\title{
APOA5 gene polymorphism assessment and association with hypertriglyceridemia in the military force of the State of Goiás
}

\author{
Avaliação do polimorfismo genético APOA5 e associação com hipertrigliceridemia na força militar \\ do Estado de Goiás \\ Evaluación del polimorfismo del gen APOA5 y asociación con la hipertrigliceridemia en la fuerza \\ militar del Estado de Goiás
}

Received: 05/18/2021 | Reviewed: 05/27/2021 | Accept: 05/31/2021 | Published: 06/14/2021

\author{
Raphael dos Reis Frazão Silva \\ ORCID: https://orcid.org/0000-0001-8296-6383 \\ Pontifícia Universidade Católica de Goiás, Brazil \\ E-mail: rafafrazaoreis@outlook.com \\ Tiago Lemos de Nascimento \\ ORCID: https://orcid.org/0000-0003-3068-395X \\ Pontifícia Universidade Católica de Goiás, Brazil \\ E-mail: tiagolemos22@ hotmail.com \\ Antônio Márcio Teodoro Cordeiro Silva \\ ORCID: https://orcid.org/0000-0003-0645-3599 \\ Universidade Católica de Goiás, Brazil \\ Faculdade da Polícia Militar do Estado de Goiás, Brazil \\ E-mail: marciocmed@gmail.com \\ Sérgio Henrique Nascente Costa \\ ORCID: https://orcid.org/0000-0002-4225-6368 \\ Pontifícia Universidade Católica de Goiás, Brazil \\ Faculdade da Polícia Militar do Estado de Goiás, Brazil \\ Universidade Federal de Goiás, Brazil \\ E-mail: sergionascente17@gmail.com \\ Frank Sousa Castro \\ ORCID: https://orcid.org/0000-0003-2293-5993 \\ Pontifícia Universidade Católica de Goiás, Brazil \\ Faculdade da Polícia Militar do Estado de Goiás, Brazil \\ E-mail: knarfcastro@gmail.com \\ Marina Alves Coelho Silva \\ ORCID: https://orcid.org/0000-0003-4325-7730 \\ Núcleo de Estudos e Pesquisas Tóxico-Farmacológicas, Brazil \\ E-mail: marinalves.coelho@gmail.com \\ Luiz Carlos da Cunha \\ ORCID: https://orcid.org/0000-0002-1525-8528 \\ Núcleo de Estudos e Pesquisas Tóxico-Farmacológicas, Brazil \\ E-mail: lucacunha@gmail.com
}

\begin{abstract}
According to the World Health Organization (WHO), dyslipidemias are determinant for the onset of cardiovascular diseases and represent more than $30 \%$ of global deaths. Changes in serum lipid levels are a direct consequence of dyslipidemia. This study aimed to verify the relationship between genetic polymorphism APOA5 and dyslipidemia. This is a case-control study with 199 officers of the military force of the state of Goiás in which the relationship between lipid profile and genetic polymorphism rs964184 was evaluated. Real-time Polymerase Chain Reaction (realtime PCR) was used to identify genetic polymorphism rs964184. Of the participants analyzed, 93\% were male and 7\% female, the lipid profile showed that 115 participants had dyslipidemia (group of cases) and 84 were within the reference range (control group). The genetic polymorphism rs964184 of the case group showed that 64.3\% (74/115) of the participants had genotype CC, $33.0 \%$ (38/115) had cg genotype and 2.6\% (3/115) had GG genotype. In the control group, 69.0\% (58/84) had genotype CC, 27.4\% (23/84) had cg genotype, 3.6\% (3/84) had GG genotype. In conclusion, the $\mathrm{G}$ alllea is related to high levels of triglycerides $(\geq 150 \mathrm{mg} / \mathrm{dL})$ and the $\mathrm{C}$ allea is related to normal HDL cholesterol levels ( $\geq 40 \mathrm{mg} / \mathrm{dL}$ ). Therefore, homozygous (GG) or heterozygous (CG) individuals are more inclined to have high triglycerides and low HDL cholesterol levels, which are associated with an increased risk of developing cardiovascular disease.
\end{abstract}

Keywords: Polymorphism; APOA5; Dyslipidemias. 


\begin{abstract}
Resumo
Segundo a Organização Mundial da Saúde (OMS), as dislipidemias são determinantes para o aparecimento de doenças cardiovasculares e representam mais de 30\% das mortes globais. Alterações nos níveis lipídeos de soro são uma consequência direta da dislipidemia. Este estudo teve como objetivo verificar a relação entre polimorfismo genético APOA5 e dislipidemia. Trata-se de um estudo de caso-controle com 199 oficiais da força militar do estado de Goiás em que foi avaliada a relação entre o perfil lipídica e o polimorfismo genético rs964184. A Reação em Cadeia de Polimerase em tempo real (PCR em tempo real) foi usada para identificar o polimorfismo genético rs964184. Dos participantes analisados, 93\% eram do sexo masculino e 7\% do feminino, o perfil lipídico mostrou que 115 participantes apresentaram dislipidemia (grupo de casos) e 84 estavam dentro da faixa de referência (grupo controle). O polimorfismo genético rs964184 do grupo de casos mostrou que 64,3\% (74/115) dos participantes apresentavam genótipo CC, 33,0\% (38/115) tinham genótipo cg e 2,6\% (3/115) tinham genótipo GG. No grupo controle, 69,0\% (58/84) apresentava genótipo CC, 27,4\% (23/84) tinham genótipo cg, 3,6\% (3/84) tinham genótipo GG. Em conclusão, o alelo $\mathrm{G}$ está relacionado a altos níveis de triglicérides $(\geq 150 \mathrm{mg} / \mathrm{dL})$ e o alelo $\mathrm{C}$ está relacionado a níveis normais de colesterol HDL ( $\geq 40 \mathrm{mg} / \mathrm{dL}$ ). Portanto, indivíduos homozigotos (GG) ou heterozigotos (CG) estão mais inclinados a ter altos triglicerídeos e baixos níveis de colesterol HDL, que estão associados a um risco aumentado de desenvolver doenças cardiovasculares.
\end{abstract}

Palavras-chave: Polimorfismo; APOA5; Dislipidemias.

\title{
Resumen
}

Según la Organización Mundial de la Salud (OMS), las dislipidemias son determinantes para la aparición de enfermedades cardiovasculares y representan más del 30\% de las muertes mundiales. Los cambios en los niveles séricos de lípidos son una consecuencia directa de la dislipidemia. Este estudio tenía como objetivo verificar la relación entre el polimorfismo genético APOA5 y la dislipidemia. Se trata de un estudio de control de casos con 199 oficiales de la fuerza militar del estado de Goiás en el que se evaluó la relación entre el perfil lipídico y el polimorfismo genético rs964184. Se utilizó reacción en cadena de la polimerasa en tiempo real (PCR en tiempo real) para identificar el polimorfismo genético rs964184. De los participantes analizados, el 93\% eran hombres y el 7\% mujeres, el perfil lipídico mostró que 115 participantes tenían dislipidemia (grupo de casos) y 84 estaban dentro del rango de referencia (grupo de control). El polimorfismo genético rs964184 del grupo de casos mostró que el 64,3\% (74/115) de los participantes tenía genotipo CC, el 33,0\% (38/115) tenía genotipo cg y el 2,6\% (3/115) tenía genotipo GG. En el grupo de control, el 69,0\% (58/84) tenía genotipo CC, el 27,4\% (23/84) tenía genotipo cg, el 3,6\% (3/84) tenía genotipo GG. En conclusión, el G alllea está relacionado con altos niveles de triglicéridos $(\geq 150 \mathrm{mg} / \mathrm{dL})$ y el C allea está relacionado con los niveles normales de colesterol HDL ( $\geq 40 \mathrm{mg} / \mathrm{dL}$ ). Por lo tanto, los individuos homocigóticos $(\mathrm{GG})$ o heterocigótigos (CG) están más inclinados a tener triglicéridos altos y bajos niveles de colesterol HDL, que se asocian con un mayor riesgo de desarrollar enfermedad cardiovascular.

Palabras clave: Polimorfismo; APOA5; Dislipidemias.

\section{Introduction}

According to the World Health Organization (WHO), cardiovascular diseases (CVD) are responsible for about 17.9 million deaths every year, among several risk factors, dyslipidemia is prominent in the development of CVDs (WHO, 2017).

Dyslipidemia is characterized as changes in serum lipid levels (ANVISA, 2011). According to the United States National Health and Nutrition Examination Survey (NHANES), about 53\% of American adults have some lipid disorder (Tóth et al., 2012). In Brazil, according to research conducted in the state of São Paulo, the prevalence of dyslipidemia in the population of the state was $59.74 \%$ (Garcez et al., 2014).

Dyslipidemias can be classified as hyperlipidemias and hypolipidemias, being etiologically characterized as primary (genetic origin) or secondary causes (unhealthy lifestyle, morbid conditions, or even medications) (SBC, 2017).

According to the type of changes in serum lipid levels, dyslipidemia is classified as follows: a) Isolated hypercholesterolemia - an isolated increase in low-density lipoprotein cholesterol (LDL-c $\geq 160 \mathrm{mg} / \mathrm{dL}$ ); b) Isolated hypertriglyceridemia - an isolated increase in triglycerides ( $\mathrm{TG} \geq 150 \mathrm{mg} / \mathrm{dL}$ or $\geq 175 \mathrm{mg} / \mathrm{dL}$, if the sample is obtained without fasting); c) Mixed hyperlipidemia - an increase in LDL-c (LDL-c $\geq 160 \mathrm{mg} / \mathrm{dL}$ ) and TG (TG $\geq 150 \mathrm{mg} / \mathrm{dL}$ or $\geq 175$ $\mathrm{mg} / \mathrm{dL}$, if the sample is obtained without fasting). When TG is $\geq 400 \mathrm{mg} / \mathrm{dL}$, the calculation of LDL-c by the Friedewald formula becomes inadequate, and mixed hyperlipidemia should be considered when high density non-cholesterol (HDL-c) is $\geq$ 
$190 \mathrm{mg} / \mathrm{dL}$; HDL-c is considered low when there is an isolated reduction in HDL-c (men $<40 \mathrm{mg} / \mathrm{dL}$ and women $<50 \mathrm{mg} /$ dL) or in association with an increase in LDL-c or TG (SBC, 2017).

Generally, dyslipidemia develops because of an unhealthy lifestyle, especially the consumption of food rich in saturated/trans fats and physical inactivity (SBC, 2017). However, genetics is responsible for changes in serum lipid levels through polymorphisms, which can alter lipid metabolism (Andrade et al., 2002).

Regarding proteins involved in lipid metabolism, the apolipoproteins (apo) are characterized as the protein component of lipoproteins, participating in the formation of its five classes: chylomicron, High Density Lipoprotein (HDL), Low Density Lipoprotein (LDL), Intermediate Density Lipoprotein (IDL) and Very Low-Density Lipoproteins (VLDL) (Novak et al., 1996).

Apolipoprotein A5 (APOA5) has been identified as a new member of apolipoproteins, being located at locus 11q23 (van der Vliet et al., 2001) and plays an important role in mediating serum TG density. The findings related to APOA5 stimulated new research to determine the association of this genetic polymorphism with the plasma lipid levels in humans (Xia et al., 2015).

According to Genome-Wide Association Study (GWAS) multiple single nucleotide polymorphisms (SNP) associated with plasma TG levels have been identified. Among them, the SNP rs964184 stands out (chromosomal position: 11q23.3: 116648917), being close to the APOA5-A4-C3-A1 gene complex (ME 606368, ME 107690, ME 107720, ME 107680) (van de Woestijne et al., 2014). Several studies reported that the APOA5 T1131C polymorphism is related to an increased risk of cardiovascular disease in different ethnic groups (Xia et al., 2015).

Physiological changes caused by stress, homeostasis, and intermediate metabolism indicate that mental stress can lead to the onset of cardiovascular diseases. In a stress situation, the human organism redistributes its energy sources, anticipating imminent aggression. This adaptation mechanism is advantageous if there is imminent danger. However, if this state persists for a long time, the damage will be inevitable. Stress can still provide an imbalance in the autonomic nervous system performance, triggering ischemic events and arrhythmias. (Loures et al., 2002).

In this context, this study aimed to assess the relation between APOA5 gene polymorphism and dyslipidemias, as well as the plasma changes in lipoproteins in military force officers of the State of Goiás.

\section{Material and Methods}

This study is part of the research project "Detection of genetic polymorphism for lipid alterations and alcohol use in the military force of the state of Goiás", submitted to the research ethics committee of the Federal University of Goiás, following the provisions of Resolution 466 / 12, of the National Health Council (NHC), and approved using Opinion No. 608, $207 / 2014$.

All 861 research participants consented to participate by signing a form. Were selected 200 participants according to lipid profile results. Those who presented hypercholesterolemia, hypertriglyceridemia, mixed hyperlipidemia was included in the case group, and those who presented normal lipid profile (HDL > $50 \mathrm{mg} / \mathrm{dL}$, total cholesterol $<190 \mathrm{mg} / \mathrm{dL}$, LDL < 160 $\mathrm{mg} / \mathrm{dL}$, and triglycerides $<150 \mathrm{mg} / \mathrm{dL}$ ) as recommended by the update of the Brazilian guideline on dyslipidemias in 2017, were included in the control group.

The biological samples were collected by the heads of the Clinical Laboratory of the Military Police Hospital of the State of Goiás. The blood samples were collected in $4 \mathrm{~mL}$ vacuum tubes with EDTA anticoagulant and were stored in the freezer at $-20^{\circ} \mathrm{C}$ and sent to the Replicon laboratory at PUC Goiás for analysis. Thus, the DNA samples used were isolated by the commercial kit Ilustra Blood Genomic Prep Mini Spin ${ }^{\circledR}$ (GE Healthcare, UK) and stored in the freezer at $-20^{\circ} \mathrm{C}$ to be used in genotyping, with the TaqMan Real-Time PCR ${ }^{\circledR}$ kit, followed by fluorescence. 
Thus, the rs964184 polymorphism was genotyped, using the TaqMan Real Time PCR® kit (SNP Genotyping Kit, Applied Biosystems, USA), which contains the sense and antisense sequences of the primers that amplify the polymorphic sequence of interest and a Probe TaqMan ${ }^{\circledR}$ specific MGB allele that hybridizes a complementary sequence of the antisense primers. The fluorophores used will be FAM and HEX. Genotyping was performed by analyzing the fluorescence pattern of each sample on the StepOnePlus ${ }^{\text {TM }}$ systems thermocycler (Applied Biosystems, USA).

The PCR reactions were performed for a final volume of $15 \mu \mathrm{L}$ containing $20 \mathrm{ng}$ of genomic DNA, $2.5 \mu \mathrm{L}$ of TaqMan® Universal Master Mix (R) (2X concentration), $0.25 \mu \mathrm{L}$ of Custom TaqMan® Assay SNP Genotyping (20X concentrated) containing both primers and probes. The amplification protocol that was used followed the manufacturer's instructions, as described below: annealing of $60^{\circ} \mathrm{C}$ for $30 \mathrm{~s}$, followed by $95^{\circ} \mathrm{C}$ for $10 \mathrm{~min}$ and then 40 cycles containing denaturation of $95^{\circ} \mathrm{C}$ for $15 \mathrm{~s}$ and annealing of $60^{\circ} \mathrm{C}$ for $1 \mathrm{~min}$ (Applied Biosystems, USA). This genetic analysis evaluated the polymorphism rs964184, which is associated with APOA5.

The serum samples were collected in $4 \mathrm{~mL}$ vacuum tubes with separating gel, which after centrifugation were used to perform the lipid profile, using enzymatic and direct methodologies in automated equipment A15 (Biosystems®), in the Clinical Laboratory of the Military Police Hospital of the State of Goiás. All quality assurance requirements have been met.

The samples were used only for the purpose of the study and at the end of the procedures, the samples were correctly disposed of according to RDC n 306/2004 of the Agência Nacional de Vigilância Sanitária (ANVISA).

For the data analysis, descriptive statistics were performed, with the determination of the absolute and relative frequencies of the variables studied. Subsequently, inferential statistics were performed using Fisher's exact and G tests for categorical variables. The comparison of means and continuous variables were performed using Student's t-test or MannWhitney. Simple logistic regression was used to evaluate the polymorphisms in the groups, with the calculation of Odds Ratio (OR), the $95 \%$ confidence interval (95\% CI), and the p-value. For all inferential tests, a significance level of 5\% was adopted. The statistical software used was BioEstat ${ }^{\circledR}$ 3.5.

\section{Results}

This was a case-control study, whose sample universe consisted of 200 active military police officers of similar ages. From this total, one participant was classified as indeterminate, due to an inconclusive result in the SNP genetic polymorphism rs964184 evaluation, totaling 199 participants in this study. Most participants in the case group were over 40 years old, while the control group showed a balance (50\%) between the ages. Dyslipidemia was observed in 115 individuals (case group), with the majority being evidenced in those who were overweight or obese. The highlighted lipid changes were the increase in total cholesterol and triglycerides and low HDL. Regarding the SNP rs964184, the CC genotype and the CG genotype were more commonly observed, while the GG genotype had a lower incidence (Table 1). 
Table 1. Frequencies absolute and relative percentage for categorical variables, 2020.

\begin{tabular}{|c|c|c|c|c|c|c|}
\hline \multirow{2}{*}{ Variables } & \multicolumn{2}{|c|}{$\begin{array}{c}\text { Case } \\
(\mathbf{N}=115)\end{array}$} & \multicolumn{2}{|c|}{$\begin{array}{l}\text { Control } \\
(\mathrm{N}=\mathbf{8 4})\end{array}$} & \multicolumn{2}{|c|}{$\begin{array}{c}\text { Total } \\
(\mathrm{N}=199) \\
\end{array}$} \\
\hline & $n$ & $f(\%)$ & $n$ & $f(\%)$ & $n$ & $f(\%)$ \\
\hline \multicolumn{7}{|l|}{ Age (years) } \\
\hline Up to 40 & 35 & 30.4 & 42 & 50.0 & 77 & 38.7 \\
\hline Over 40 & 80 & 69.6 & 42 & 50.0 & 122 & 61.3 \\
\hline \multicolumn{7}{|l|}{ Sex } \\
\hline Male & 108 & 93.9 & 77 & 91.7 & 185 & 93.0 \\
\hline Female & 7 & 6.1 & 7 & 8.3 & 14 & 7.0 \\
\hline \multicolumn{7}{|l|}{ Serum Aspect } \\
\hline Clear & 68 & 59.1 & 84 & 100.0 & 152 & 76.4 \\
\hline Slightly cloudy & 34 & 29.6 & 0 & 0.0 & 34 & 17.1 \\
\hline Lipemic & 13 & 11.3 & 0 & 0.0 & 13 & 6.5 \\
\hline \multicolumn{7}{|l|}{ Total Cholesterol (mg/dL) } \\
\hline$<190$ & 37 & 32.2 & 61 & 72.6 & 98 & 49.2 \\
\hline$>190$ & 78 & 67.8 & 23 & 27.4 & 101 & 50.8 \\
\hline \multicolumn{7}{|l|}{ Triglycerides (mg/dL) } \\
\hline$<150$ & 21 & 18.3 & 84 & 100.0 & 105 & 52.8 \\
\hline$>150$ & 94 & 81.7 & 0 & 0.0 & 94 & 47.2 \\
\hline \multicolumn{7}{|l|}{ HDL (mg/dL) } \\
\hline$<40(\mathrm{M})<50(\mathrm{~F})$ & 95 & 82.6 & 39 & 46.4 & 134 & 67.3 \\
\hline$>40(\mathrm{M})>50(\mathrm{~F})$ & 20 & 17.4 & 45 & 53.6 & 65 & 32.7 \\
\hline \multicolumn{7}{|l|}{ Non-HDL cholesterol (mg/dL) } \\
\hline$<190$ & 69 & 60.0 & 84 & 100.0 & 153 & 76.9 \\
\hline$>190$ & 46 & 40.0 & 0 & 0.0 & 46 & 23.1 \\
\hline \multicolumn{7}{|l|}{ LDL (mg/dL) } \\
\hline$<160$ & 86 & 74.8 & 84 & 100.0 & 170 & 85.4 \\
\hline$>160$ & 26 & 22.6 & 0 & 0.0 & 26 & 13.1 \\
\hline Indeterminate & 3 & 2.6 & 0 & 0.0 & 3 & 1.5 \\
\hline \multicolumn{7}{|l|}{ BMI (kg/m2) } \\
\hline Low Normal Weight $(<18.5)$ & 0 & 0.0 & 0 & 0.0 & 0 & 0.0 \\
\hline Normal Weight (18.5 to 24.9 ) & 11 & 9.6 & 29 & 34.5 & 40 & 20.1 \\
\hline Overweight (25.0 to 29.9 ) & 59 & 51.3 & 47 & 56.0 & 106 & 53.3 \\
\hline Obesity (> 30.0) & 34 & 29.6 & 6 & 7.1 & 40 & 20.1 \\
\hline $\mathrm{NC}$ & 11 & 9.6 & 2 & 2.4 & 13 & 6.5 \\
\hline \multicolumn{7}{|l|}{ rs964184 } \\
\hline $\mathrm{CC}$ & 74 & 64.3 & 58 & 69.0 & 132 & 66.3 \\
\hline CG & 38 & 33.0 & 23 & 27.4 & 61 & 30.7 \\
\hline GG & 3 & 2.6 & 3 & 3.6 & 6 & 3.0 \\
\hline
\end{tabular}

n: absolute frequency; f (\%): percentage relative frequency; G: guanine; T: thymine; M: male; F: female; HDL: High Density Lipoprotein; LDL: Low Density Lipoprotein; BMI: Body Mass Index.

Source: Authors themselves.

The average age of the participants was $43.4 \pm 8.5$ years old for the case group and $39.8 \pm 5.5$ years old for the control group. Regarding the means of the continuous variables, there were significant differences in almost all variables, only the variable"height" did not show a significant difference $(\mathrm{p}=0.0966)$, according shown in Table 2. 
Table 2. Mean, standard deviation, amplitude, and p-value of continuous variables, 2020.

\begin{tabular}{|c|c|c|c|c|c|}
\hline \multirow[t]{2}{*}{ Variable } & \multicolumn{2}{|c|}{ Case $(N=116)$} & \multicolumn{2}{|c|}{ Control $(\mathrm{N}=84)$} & \multirow{2}{*}{ p-value } \\
\hline & Average & $D P$ & Average & $D P$ & \\
\hline Age (Years) & 43.4 & 5.5 & 39.8 & 8.5 & 0.0049 \\
\hline Min - Max & 29 & 55 & 23 & 56 & \\
\hline Total cholesterol (mg/dL) & 214.5 & 44.6 & 169.2 & 27.4 & $<0.0001$ \\
\hline Min - Max & 118 & 337 & 107 & 227 & \\
\hline Triglycerides (mg/dL) & 268.9 & 192.6 & 85.3 & 32.3 & $<0.0001$ \\
\hline Min - Max & 63 & 1242 & 25 & 149 & \\
\hline HDL (mg/dl) & 42.3 & 8.3 & 51.3 & 9.3 & $<0.0001 *$ \\
\hline Min - Max & 25 & 66 & 40 & 102 & \\
\hline Non-HDL cholesterol (mg/dL) & 172.2 & 40.9 & 117.9 & 27.7 & $<0.0001$ \\
\hline Min - Max & 79 & 281 & 59 & 183 & \\
\hline LDL (mg/dL) & 123.3 & 43.7 & 100.9 & 26.5 & 0.0003 \\
\hline Min - Max & 38 & 235 & 40 & 158 & \\
\hline Weight (Kg) & 87.5 & 13.2 & 77.9 & 10.2 & $<0.0001$ \\
\hline Min - Max & 60 & 155 & 51 & 101 & \\
\hline Height (m) & 1.74 & 0.06 & 1.73 & 0.06 & $0.0966 *$ \\
\hline Min - Max & 1.65 & 1.93 & 1.58 & 1.88 & \\
\hline BMI $\left(\mathrm{Kg} / \mathrm{m}^{2}\right)$ & 28.66 & 3.38 & 25.97 & 2.66 & $<0.0001$ \\
\hline Min - Max & 21.26 & 43.85 & 19.60 & 31.90 & \\
\hline
\end{tabular}

Cases $x$ control were compared. All by Mann-Whitney test, except (*) Student's t-test. n: number; f (\%): frequency; G: guanine; T: thymine; M: male; F: female; HDL: High Density Lipoprotein; LDL: Low Density Lipoprotein; BMI: Body Mass Index; Min: Minimum; Max: Maximum.

Source: Authors themselves.

The rs964184 polymorphism showed to be related to dyslipidemia evidenced in the case group, among genotypes CC, CG, and GG. The highlighted variables were: increased levels in total cholesterol and triglycerides, and decreased levels in HDL cholesterol compared to the reference values (Table 3). 
Table 3. Absolute frequencies and relative percentages for the rs 964184 polymorphism, 2020.

\begin{tabular}{|c|c|c|c|c|c|c|c|c|c|c|c|c|}
\hline \multirow{3}{*}{ Variable (mg/dL) } & \multicolumn{2}{|c|}{ Control } & \multicolumn{10}{|c|}{ Case } \\
\hline & \multicolumn{2}{|c|}{$\begin{array}{c}\mathrm{CC} \\
(\mathrm{N}=74)\end{array}$} & \multicolumn{2}{|c|}{$\begin{array}{c}C G \\
(N=38)\end{array}$} & \multicolumn{2}{|c|}{$\begin{array}{c}\text { GG } \\
(\mathbf{N}=3)\end{array}$} & \multirow{2}{*}{$\begin{array}{c}\mathrm{CC} \\
(\mathbf{N}=58) \\
n\end{array}$} & \multicolumn{2}{|c|}{$\begin{array}{c}C G \\
(N=23)\end{array}$} & \multicolumn{3}{|c|}{$\begin{array}{c}\text { GG } \\
(\mathbf{N}=\mathbf{3})\end{array}$} \\
\hline & $n$ & $\underset{(\%)}{f}$ & $n$ & $\underset{(\%)}{f}$ & $n$ & $\underset{(\%)}{f}$ & & $\underset{(\%)}{f}$ & $n$ & $\underset{(\%)}{f}$ & $n$ & $\underset{(\%)}{f}$ \\
\hline \multicolumn{13}{|l|}{ Total Cholesterol } \\
\hline$<190$ & 20 & 27.0 & 16 & 42.1 & 1 & 33.3 & 40 & 69.0 & 18 & 78.3 & 3 & 100.0 \\
\hline$>190$ & 54 & 73.0 & 22 & 57.9 & 2 & 66.7 & 18 & 31.0 & 5 & 21.7 & 0 & 0.0 \\
\hline \multicolumn{13}{|l|}{ Triglycerides } \\
\hline$<150$ & 18 & 24.3 & 3 & 7.9 & 0 & 0.0 & 58 & 100.0 & 23 & 100.0 & 3 & 100.0 \\
\hline$>150$ & 56 & 75.7 & 35 & 92.1 & 3 & 100.0 & 0 & 0.0 & 0 & 0.0 & 0 & 0.0 \\
\hline \multicolumn{13}{|l|}{ HDL } \\
\hline$<40(\mathrm{M})<50(\mathrm{~F})$ & 58 & 78.4 & 34 & 89.5 & 3 & 100.0 & 26 & 44.8 & 12 & 52.2 & 1 & 33.3 \\
\hline$>40(\mathrm{M})>50(\mathrm{~F})$ & 16 & 21.6 & 4 & 10.5 & 0 & 0.0 & 32 & 55.2 & 11 & 47.8 & 2 & 66.7 \\
\hline \multicolumn{13}{|c|}{ Non-HDL cholesterol } \\
\hline$<190$ & 43 & 58.1 & 24 & 63.2 & 2 & 66.7 & 58 & 100.0 & 23 & 100.0 & 3 & 100.0 \\
\hline$>190$ & 31 & 41.9 & 14 & 36.8 & 1 & 33.3 & 0 & 0.0 & 0 & 0.0 & 0 & 0.0 \\
\hline \multicolumn{13}{|l|}{ LDL * } \\
\hline$<160$ & 51 & 69.9 & 32 & 88.9 & 3 & 100.0 & 58 & 100.0 & 23 & 100.0 & 3 & 100.0 \\
\hline$>160$ & 22 & 30.1 & 4 & 11.1 & 0 & 0.0 & 0 & 0.0 & 0 & 0.0 & 0 & 0.0 \\
\hline
\end{tabular}

n: number; f (\%): frequency; G: guanine; T: thymine; M: male; F: female; HDL: High Density Lipoprotein; LDL: Low Density Lipoprotein; BMI: Body Mass Index.

Source: Authors themselves.

The $\mathrm{C}$ allele dominant is associated with low triglyceride values $(\mathrm{OR}=0.0028$; CI95\% $=0.000-0.022)$. The Odds Ratio (OR) values for HDL, with the $\mathrm{C}$ allele dominant, showed that this allele guarantees greater protection for the development of atherogenesis $(\mathrm{OR}=5.2053$; CI95\% $=2.714-9.985)$ (Table 4).

Table 4. Absolute frequencies and relative percentages for the APOA5 rs964184 polymorphism, with the C allele dominant, 2020.

\begin{tabular}{|c|c|c|c|c|c|c|c|c|c|c|c|}
\hline \multirow{3}{*}{$\begin{array}{l}\text { Variable } \\
(\mathrm{mg} / \mathrm{dL})\end{array}$} & \multicolumn{4}{|l|}{ Case } & \multicolumn{4}{|c|}{ Control } & \multirow{3}{*}{$\mathbf{O R}$} & \multirow{2}{*}{\multicolumn{2}{|c|}{$95 \% \mathrm{CI}$}} \\
\hline & \multicolumn{2}{|c|}{$\begin{array}{l}\mathbf{C C}+\mathbf{C G} \\
(\mathrm{N}=112) \\
\end{array}$} & \multicolumn{2}{|c|}{$\begin{array}{c}\text { GG } \\
(\mathbf{N}=\mathbf{3})\end{array}$} & \multicolumn{2}{|c|}{$\begin{array}{c}\mathbf{C C}+\mathbf{C G} \\
(\mathbf{N}=\mathbf{8 1})\end{array}$} & \multicolumn{2}{|c|}{$\begin{array}{c}\text { GG } \\
(\mathbf{N}=\mathbf{3})\end{array}$} & & & \\
\hline & $n$ & $f(\%)$ & $n$ & $f(\%)$ & $n$ & $f(\%)$ & $n$ & $f(\%)$ & & $\operatorname{Inf}$ & Sup \\
\hline \multicolumn{12}{|l|}{ Total Cholesterol } \\
\hline$<190$ & 36 & 32.1 & 1 & 33.3 & 58 & 71.6 & 3 & 100.0 & & & \\
\hline$>190$ & 76 & 67.9 & 2 & 66.7 & 23 & 28.4 & 0 & 0.0 & 0.1870 & 0.101 & 0.351 \\
\hline \multicolumn{12}{|l|}{ Triglycerides } \\
\hline$<150$ & 21 & 18.8 & 0 & 0.0 & 81 & 100.0 & 3 & 100.0 & & & \\
\hline$>150$ & 91 & 81.3 & 3 & 100.0 & 0 & 0.0 & 0 & 0.0 & 0.0028 & 0.000 & 0.022 \\
\hline \multicolumn{12}{|l|}{ HDL } \\
\hline$<40(\mathrm{M})<50(\mathrm{~F})$ & 92 & 82.1 & 3 & 100.0 & 38 & 46.9 & 1 & 33.3 & & & \\
\hline$>40(\mathrm{M})>50(\mathrm{~F})$ & 20 & 17.9 & 0 & 0.0 & 43 & 53.1 & 2 & 66.7 & 5.2053 & 2.714 & 9.985 \\
\hline \multicolumn{12}{|c|}{ Non-HDL cholesterol } \\
\hline$<190$ & 67 & 59.8 & 2 & 66.7 & 81 & 100.0 & 3 & 100.0 & & & \\
\hline$>190$ & 45 & 40.2 & 1 & 33.3 & 0 & 0.0 & 0 & 0.0 & 0.0184 & 0.003 & 0.137 \\
\hline \multicolumn{12}{|l|}{ LDL } \\
\hline$<160$ & 83 & 74.1 & 3 & 100.0 & 81 & 100.0 & 3 & 100.0 & & & \\
\hline$>160$ & 26 & 23.2 & 0 & 0.0 & 0 & 0.0 & 0 & 0.0 & 0.0394 & 0.005 & 0.297 \\
\hline
\end{tabular}

n: number; f (\%): frequency; G: guanine; T: thymine; M: male; F: female; HDL: High Density Lipoprotein; LDL: Low Density Lipoprotein; OR = Odds Ratio; 95\% CI: 95\% Confidence Interval. Source: Authors themselves. 
The $\mathrm{G}$ allele dominant maintained the results when compared to the $\mathrm{C}$ allele dominant, the $\mathrm{OR}$ of triglycerides was very low demonstrating a greater chance of developing hypertriglyceridemia among the participants, while the HDL OR also presented a high value guaranteeing the protective factor $(\mathrm{OR}=4.4615$; CI95\% $=2.091-9.518)($ Table 5).

Table 5. Absolute frequencies and relative percentages for the APOA5 rs964184 polymorphism, with the G allele dominant, 2020.

\begin{tabular}{|c|c|c|c|c|c|c|c|c|c|c|c|}
\hline \multirow{3}{*}{$\begin{array}{l}\text { Variable } \\
(\mathrm{mg} / \mathrm{dL})\end{array}$} & \multicolumn{4}{|c|}{ Case } & \multicolumn{4}{|c|}{ Control } & \multirow[t]{3}{*}{ OR } & \multicolumn{2}{|c|}{$95 \% \mathrm{CI}$} \\
\hline & \multicolumn{2}{|c|}{$\begin{array}{c}C C \\
(N=74)\end{array}$} & \multicolumn{2}{|c|}{$\begin{array}{c}\mathbf{C G}+\mathbf{G G} \\
(\mathbf{N}=\mathbf{4 1})\end{array}$} & \multicolumn{2}{|c|}{$\begin{array}{c}\mathrm{CC} \\
(\mathrm{N}=58)\end{array}$} & \multicolumn{2}{|c|}{$\begin{array}{c}\mathbf{C G}+\mathbf{G G} \\
(\mathbf{N}=26)\end{array}$} & & \multirow[b]{2}{*}{ Inf } & \multirow[b]{2}{*}{ Sup } \\
\hline & $n$ & $\underset{(\%)}{f}$ & $n$ & $\underset{(\%)}{f}$ & $n$ & $\underset{(\%)}{f}$ & $n$ & $\underset{(\%)}{f}$ & & & \\
\hline \multicolumn{12}{|l|}{ Total Cholesterol } \\
\hline$<190$ & 20 & 27.0 & 17 & 41.5 & 40 & 69.0 & 21 & 80.8 & & & \\
\hline$>190$ & 54 & 73.0 & 24 & 58.5 & 18 & 31.0 & 5 & 19.2 & 0.1667 & 0.078 & 0.355 \\
\hline \multicolumn{12}{|l|}{ Triglycerides } \\
\hline$<150$ & 18 & 24.3 & 3 & 7.3 & 58 & 100.0 & 26 & 100.0 & & & \\
\hline$>150$ & 56 & 75.7 & 38 & 92.7 & 0 & 0.0 & 0 & 0.0 & 0.0055 & 0.001 & 0.043 \\
\hline \multicolumn{12}{|l|}{ HDL } \\
\hline$<40(\mathrm{M})<50(\mathrm{~F})$ & 58 & 78.4 & 37 & 90.2 & 26 & 44.8 & 13 & 50.0 & & & \\
\hline $40(\mathrm{M})>50(\mathrm{~F})$ & 16 & 21.6 & 4 & 9.8 & 32 & 55.2 & 13 & 50.0 & 4.4615 & 2.091 & 9.518 \\
\hline \multicolumn{12}{|c|}{ Non-HDL cholesterol } \\
\hline$<190$ & 43 & 58.1 & 26 & 63.4 & 58 & 100.0 & 26 & 100.0 & & & \\
\hline$>190$ & 31 & 41.9 & 15 & 36.6 & 0 & 0.0 & 0 & 0.0 & 0.0000 & 0.000 & 0.000 \\
\hline \multicolumn{12}{|l|}{ LDL } \\
\hline$<160$ & 51 & 68.9 & 35 & 85.4 & 58 & 100.0 & 26 & 100.0 & & & \\
\hline$>160$ & 22 & 29.7 & 4 & 9.8 & 0 & 0.0 & 0 & 0.0 & 0.0000 & 0.000 & 0.000 \\
\hline
\end{tabular}

n: number; f (\%): frequency; G: guanine; T: thymine; M: male; F: female; HDL: High Density Lipoprotein; LDL: Low Density Lipoprotein; OR = Odds Ratio; 95\% CI: 95\% Confidence Interval.

Source: Authors themselves.

\section{Discussion}

Dyslipidemia is one of the main risk factors for the development of cardiovascular diseases (Moreira et al., 2006), the association between high levels of triglycerides and low levels of HDL cholesterol are common findings among patients with cardiovascular diseases. A similar association was observed in the case group assessed by this study.

Genetic factors are able to influence serum triglyceride levels, independently (van de Woestijne et al., 2014). The present study highlights that the polymorphism rs964184 of the APOA5 gene can directly influence the increase in triglycerides and total cholesterol. Similar results were reported by Woestijne et al. (2014), which observed a strong association of such polymorphism with triglyceride levels and a minor association with HDL-cholesterol levels.

Another study performed with the Chinese population $(\mathrm{N}=5347)$ assessing the SNP rs964184, reported an association of polymorphism with increased triglyceride levels and significant relation between the six SNPs genotypes and the triglyceride levels $(P<0.008)$ (Fu et al., 2015).

Following the association of the rs964184 polymorphism with the risk of developing coronary heart disease, Xu and collaborators (2018), reported lower TG levels in older patients and suggested that these results were due to the use of drugs 
able to reduce this lipid rates in this age group. A similar result was observed in this study since lipid alterations were more associated with the population over 40 years old $(69.6 \%)$.

The same study demonstrated that the male gender had a greater association with TG levels, significantly lower for men $(p=4.79 \times 10-7)$ when compared to women $(p=0.716)$. The participants in the present study were predominantly men, with a total of 14 women, 7 belonging to the case group and 7 to the control group, whose results were similar.

This study demonstrated a greater association with the genotypes CG + GG and hypertriglyceridemia when compared to the CC genotype, being consistent with previous results performed in Iran and Tibet populations (Mirhafez et al., 2016; Parra et al., 2017; Zhang et al., 2012). Another observation about genotypes made by this study was the association of the G allele from SNP rs964184 with decreased levels of HDL, LDL, and total cholesterol, confirming the results previously reported (Zhang et al., 2012).

The polymorphism of rs964184 is directly related to high levels of triglycerides, which is a risk factor for the development of cardiovascular diseases. The application of polymorphism assessment can be used in nutrigenetics, which allows the detection of risks of these diseases through the genetic profile, demonstrating the necessity of changing habits in diet and lifestyle. Such fact could be observed in the present study, in which about $80 \%$ of the participants were overweight or obese, in addition to the change in lipid levels, and in this context, nutrigenetics could collaborate, as it is the study of the interaction between eating habits and the genetic makeup of individuals (Rimbach; Minihane, 2009).

Work tension may contribute to glucose disorders, justifying the higher risk of developing diabetes due to alcoholism, smoking, obesity, and sedentary lifestyle, but lipid levels or changes in pressure did not occur. The association between stress and coronary heart disease is mainly related to lifestyle and hyperglycemia. There are other potential biological stress factors to be analyzed such as chronic inflammation, blood-clotting factors, and increased risk of stress response that act as a stimulus of cardiac events (Nyberg et al., 2013).

The APOA5 gene is not the only one directly related to changes in TG levels, the APOE is another apolipoprotein that plays an important role in lipid metabolism that demonstrates a direct relationship in the increase of TG and consequently the increase in the risk of developing cardiovascular diseases (Demirag et al., 2007; Hagberg et al., 2000).

\section{Conclusion}

The APOA5 rs964184 gene polymorphism showed an important influence on increasing triglycerides levels and reducing the rate of HDL cholesterol, which is also related to the development of coronary diseases. The presence of the G allele in homozygosity or heterozygosity of the polymorphism rs964184 of the APOA5 gene was directly related to hypertriglyceridemia and decreasing HDL cholesterol, consequently, associated with a higher risk of developing cardiovascular diseases.

We recommend that there be future research based on apolipoproteins and cardiovascular diseases for possible treatments.

\section{Acknowledgments}

We thank to Fundação de Amparo a Pesquisa do Estado de Goiás (FAPEG) for the financial support.

\section{References}

Andrade, F. M. \& Hutz, M. H. (2002). O componente genético da determinação dos lipídeos séricos. Ciênc. Saúde Coletiva 7, 175-82. https://doi.org/10.1590/S1413-81232002000100016 
ANVISA (2011). Dislipidemia. Saúde e Economia 3(6): 1-4 (3)

Demirag, M. D., Onen, H. I., Karaoguz, M. Y. et al. (2007). Apolipoprotein E Gene Polymorphism in Nonalcoholic Fatty Liver Disease. Dig Dis Sci 52, 3399-3403. https://doi.org/10.1007/s10620-007-9740-5

Fu, Q., Tang, X., Chen, J., Su, L., et al. (2015). Effects of Polymorphisms in APOA4-APOA5-ZNF259-BUD13 Gene Cluster on Plasma Levels of Triglycerides and Risk of Coronary Heart Disease in a Chinese Han Population. PLoS One. 10(9): e0138652.

Garcez, M. R., Pereira, J. L., Fontanelli, M. M., Marchioni, D. M. L., et al. (2014). Prevalence of Dyslipidemia According to the Nutritional Status in a Representative Sample of São Paulo. Arq. Bras. Cardiol. 103(6): 476-484.

Hagberg, J. M., Wilund, K. R., \& Ferrell, R. E. (2000). APO E gene and gene-environment effects on plasma lipoprotein-lipid levels. Physiol Genomics.4(2):101-108. Published 2000 Dec 18. doi:10.1152/physiolgenomics.2000.4.2.101

Loures, D. L, Sant'Anna, I, Baldotto, C. S. R. da, et al. (2002). Estresse Mental e Sistema Cardiovascular. Arq. Bras. Cardiol.7: 525-530. http://dx.doi.org/10.1590/S0066-782X2002000500012

Mirhafez, S. R., Avan, A., Pasdar, A, Khatamianfar, S., et al. (2016) Zinc Finger 259 Gene Polymorphism rs964184 is Associated with Serum Triglyceride Levels and Metabolic Syndrome. Int. J. Mol. Cell. Med. 5(1):8-18.

Moreira, R. O., Santos, R. D., Martinez, L., Saldanha, F. C., Pimenta, J. L.A. C., et al. (2006). Perfil lipídico de pacientes com alto risco para eventos cardiovasculares na prática clínica diária. Arq. Bras. Endocrinol. Metab. 50(3): 481-489.

Novak, E. M., \& Bydlowski, S. P. (1996). Biologia Molecular das Dislipidemias. Variação Genética das Apolipoproteínas. Arq. Bras. Cardiol. 67(6): 411-417.

Nyberg, S. T., Fransson, E. I., Heikkilä, K., et al. (2013). Job strain and cardiovascular disease risk factors: meta-analysis of individual-participant data from 47,000 men and women. PLoS One.8(6):e67323. 10.1371/journal.pone.0067323

Parra, E. J., Mazurek, A., Gignoux, C. R., Sockell, A., et al. (2017). Admixture mapping in two Mexican samples identifies significant associations of locus ancestry with triglyceride levels in the BUD13/ZNF259/APOA5 region and fine mapping points to rs964184 as the main driver of the association signal. PLoS One. 12(2): e0172880.

SBC - Sociedade Brasileira de Cardiologia (2017). Atualização da diretriz brasileira de dislipidemias e prevenção da aterosclerose. Arq. Bras. Cardiol.109(1): 76.

Tóth, P. P., Potter, D., \& Ming, E. E. (2012). Prevalence of lipid abnormalities in the United States: The National Health and Nutrition Examination Survey 2003-2006. J. Clin. Lipidol. 6(4): 325-330.

Van der Vliet, H. N., Sammels, M. G., Leegwater, A. C., Levels, J. H., et al. (2001). A Novel Apolipoprotein Associated with an Early Phase of Liver Regeneration. J. Biol. Chem. 276: 44512-44520.

Van de Woestijne, A. P., van der Graaf, Y., de Bakker, P. I., Asselbergs, F. W., et al. (2014). Rs964184 (APOA5-A4-C3-A1) Is Related to Elevated Plasma Triglyceride Levels, but Not to an Increased Risk for Vascular Events in Patients with Clinically Manifest Vascular Disease. PLoS One. 9(6): e101082.

WHO (2017). Cardiovascular diseases (CVDs). Disponível em [https://www.who.int/en/news-room/fact-sheets/detail/cardiovascular-diseases-(cvds)].

WHO (2017). Cardiovascular diseases (CVDs). Disponível em [https://www.who.int/health-topics/cardiovascular-diseases/\#tab=tab_1].

Xia, J., Cai, W., Peng, C. (2015) Association of APOA5 T1131C polymorphism and risk of coronary artery disease. Int. J. Clin. Exp. Med. 8(6):8986-8994.

Xu, X., Li, Y., Huang, Y., Ye, H., et al. (2018). Impact of gender and age on the association of the BUD13-ZNF259 rs964184 polymorphism with coronary heart disease. Anatol. J. Cardiol. 19(1): 42-49.

Zhang, L. X., Sun, Y., Liang, Y., Li, K., et al. (2012). Relationship between dyslipidemia and gene polymorphism in Tibetan population. Biomed. Environ. Sci. 25(3): $305-10$.

Zhang, X., Qi, Q., Bray, G. A., Hu, F. B., Sacks, F. M., et al. (2012). APOA5 genotype modulates 2-y changes in lipid profile in response to weight-loss diet intervention: The Pounds Lost Trial. Am. J. Clin. Nutr. 96(4): 917-922. 